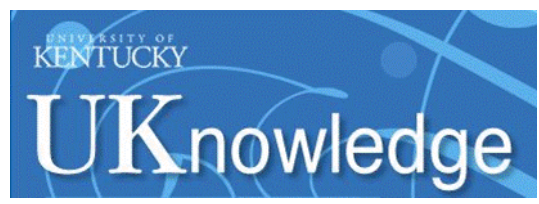

University of Kentucky

UKnowledge

Gender and Women's Studies Faculty

Publications

Gender and Women's Studies

Spring 2019

\title{
Opposing Abortion to Protect Women: Transnational Strategy since the 1990s
}

\author{
Carol Mason \\ University of Kentucky, carol.mason@uky.edu
}

Follow this and additional works at: https://uknowledge.uky.edu/gws_facpub

Part of the Women's Studies Commons

Right click to open a feedback form in a new tab to let us know how this document benefits you.

\section{Repository Citation}

Mason, Carol, "Opposing Abortion to Protect Women: Transnational Strategy since the 1990s" (2019).

Gender and Women's Studies Faculty Publications. 3.

https://uknowledge.uky.edu/gws_facpub/3

This Article is brought to you for free and open access by the Gender and Women's Studies at UKnowledge. It has been accepted for inclusion in Gender and Women's Studies Faculty Publications by an authorized administrator of UKnowledge. For more information, please contact UKnowledge@lsv.uky.edu. 


\section{Opposing Abortion to Protect Women: Transnational Strategy since the 1990s}

\section{Digital Object Identifier (DOI)}

https://doi.org/10.1086/701156

\section{Notes/Citation Information}

Published in Signs, v. 44, no. 3.

(C) 2019 by The University of Chicago. All rights reserved.

The copyright holder has granted the permission for posting the article here. 


\section{Opposing Abortion to Protect Women: Transnational Strategy since the 1990s}

$\mathrm{T}$

his article examines the transnational work that since the 1990s has increasingly opposed abortion in terms of protecting women. Two recent books detail the women-centric work of antiabortion efforts, but they fall short of examining how such politics reflect or contribute to the global rise of the Right, which also has deployed pro-woman stances strategically. Karissa Haugeberg's Women against Abortion: Inside the Largest Moral Reform Movement of the Twentieth Century (2017) and Paul Saurette and Kelly Gordon's The Changing Voice of the Anti-abortion Movement: The Rise of "Pro-Woman" Rhetoric in Canada and the United States (2016) are excellent books that recognize the roles that women have played in opposing abortion and the impact of arguing against abortion in the name of protecting women. Women against Abortion is largely biographical, focusing on a variety of US women who worked in so-called crisis pregnancy centers, staffed religious and secular "pro-life" organizations, participated in direct-action attempts to close clinics, and committed acts of violence against physicians who provided abortions. The Changing Voice of the Anti-abortion Movement is a study of "pro-woman" rhetoric that shapes legislative reform of abortion regulations and antiabortionists' strategies. Both books successfully repaint the "traditional portrait" of antiabortionists by shifting focus away from the scolding male zealot who typically gets portrayed in the news (Saurette and Gordon 2016, 152).

What these two books lack is a larger, intersectional scope of how prowoman rhetoric is used to foster right-wing politics by way of, and beyond, the fight over abortion. Putting a female front on politics meant to diminish women's political power is an old tactic of right-wing populism, European fascism, and organized white supremacism in the United States. These political projects historically have cited protecting or advancing women as their motive. Among the many new studies that examine conservative women activists and politicians in the United States and around the world, Sara

I want to thank Leslie Reagan, Karen Petrone, Toby Beauchamp, Charlie Zhang, Chip Berlet, Robin Marty, Jenn Hunt, and the editorial team of Signs for leads and insights. I am also grateful for funds from the College of Arts and Sciences at the University of Kentucky, which allowed for research assistance provided by Kyle Eveleth and Rory Barron.

[Signs: Journal of Women in Culture and Society 2019, vol. 44, no. 3]

(c) 2019 by The University of Chicago. All rights reserved. 0097-9740/2019/4403-0006\$10.00 
Farris's In the Name of Women's Rights: The Rise of Femonationalism explains how the theme of gender equality "become[s] the common currency in the name of which new racist and imperialist configurations of power become hegemonic." This book recognizes not only how the idea of gender equality "can quite easily be used opportunistically" by right-wing forces to gain political power and cultural capital but also how this opportunism is currently being deployed by neoliberal states, female politicians, and women's organizations in a way that consigns migrant (especially Muslim) women to the social reproduction that those politicians and organizations have historically sought to avoid themselves (Farris 2017, 8). Farris's intersectional approach to the trend of right-wing politics deploying pro-woman rhetoric assumes that gendered politics are always also racial and colonialist politics. This assumption is shared by feminists who for more than twenty-five years have merged reproductive rights and social justice perspectives to challenge and expand the terms of the abortion debate. Inspired by Farris's study and by the generations of reproductive justice scholars and activists who have done such expansive work for decades, this article examines the pro-woman impulse of antiabortion politics in a transnational and intersectional framework.

We should not view the pro-woman stances against abortion dismissively, as only a matter of cynical political opportunism, or naively, as earnest political or moral expression by conservative, Catholic, and evangelical Christian women. It is important to consider the cultural work as well as the political gains achieved by arguing against abortion in the name of women's rights. For example, it broadens our scope to see this current championing of women and womanhood in the historical context and cultural moment in which these concepts, on the one hand, are complicated by transgender and other members of the LGBTQ community and, on the other, are exalted by conservative Christians who see womanhood as an institution besieged by transgender and gender-nonconforming people. In October 2015, a gathering billed as the "first-ever evangelical conference on transgender issues" was cosponsored by the Council for Biblical Manhood and Womanhood, the name of which exemplifies the religious Right's territorializing of gender-understood as the binary of manhood and womanhood - as a specifically Christian property (Smith 2015). To protect this property of womanhood, policies regarding the gendered use of public toilets proliferated after the 2015 conference. In the name of protecting girls and women, campaigns for "bathroom bills" and for pro-woman antiabortion bills alike depict predators preying specifically on white women and girls. In public toilets, white women and girls are portrayed as being victimized by sexual predators (Beauchamp 2018). In abortion clinics, white women and girls are portrayed as being victimized by all sorts of predators - moral, financial, sexual, racial, Semitic, and satanic- 
or a conglomeration of all of these (Mason 2002, 158-86; Saurette and Gordon 2016, 260). While US campaigns that claim to want to protect black women and black "unborn" babies from abortion emerge intermittently, especially during elections in hopes of splitting the African American vote (Joyce 2010), by and large the so-called victims of abortion (when not exclusively seen as the so-called unborn) are depicted visually as white women or statistically as "women," the universal category that is understood by default to be white (Saurette and Gordon 2016, 260, 285). The understood whiteness of these women who supposedly need protection is important to consider.

As with other right-wing movements worldwide and historically, US antiabortion rhetoric increasingly redeploys colonial and civilizational narratives about white women as victims. As victims of abortion as a medical procedure, women purportedly suffer postabortion mental illness or physical disease allegedly caused by terminating pregnancies. As victims of an abortion "industry," white women purportedly suffer sexual abuse and financial exploitation at the hands of doctors and clinic personnel. Such narratives depicting white women as dupes of a sordid, satanic system of abortion provision ignore the fact that most women report feeling relief-not grief, regret, or trauma - after terminating an unwanted pregnancy (Sanger 2017). These narratives thus follow a "tendency to monopolize and capitalize on victimhood" whenever "whiteness feminizes" (Chow 2002, 179). To get a sense of the political and cultural influence that right-wing movements gain when they play the woman card, we can trace the transnational traffic among antiabortion personnel, funds, and tactics. When we read "representations of 'woman' cross-culturally by foregrounding the issue of ethnicityincluding the ethnicity of whiteness"-we can explore the "racialist hold on victimhood itself as cultural capital" (Chow 2002, 179). This article thus analyzes representations of women as victims of abortion, focusing on three countries where national identity is especially bound up with whiteness and where abortion has been particularly contested: Ireland, Russia, and the United States. In so doing, I hope to illuminate how transnational antiabortion work plays a role in the global rise of the Right that characterizes the contemporary moment.

So far, antiabortion politics have received little attention in analyses that have tried to account for the surprise election of Donald Trump in the United States, the unexpected vote by the British to exit the European Union, the unanticipated embrace of Marine LePen as a French presidential candidate in 2017, and the political triumph of populists and the far Right in 2018 in Italy (to name but a few indicators of a global rise of the Right). In fact, a recent study decentered the role of abortion in the history of conservatism's rise in the United States, suggesting that instead of abortion it actually was racism that shaped the forces of the New Right and the Reagan revolution (Balmer 
2014). This study ignored and effectively undid (in the eyes of the media) intersectional analyses of abortion politics as profoundly imbued with racial implications and historically inextricable from racial politics (e.g., Roberts 1998). While the politics of gender were front and center in the aftermath of Hillary Clinton's defeat by a self-described pussy-grabber, no one has compared strategy and tactics between antiabortion militants and the alt-right, even though their campus activities resemble each other. No one has considered how the mass hoaxes, media manipulation and harassment, and "fake news" of the Trump era were all presaged by the scare tactics, faux documentaries, and doxing practices of militant antiabortionists. By looking at "pro-woman" opposition to abortion in a transnational light, this article attempts to fill in some of these gaps in inquiry and invites others to further the investigation.

What follows is a three-part examination. First I consider how antiabortionists comprising a nonmilitant global pro-life network export their message and embrace a rationalist discourse in which the state is good and useful and passing legislation is a goal. This first part of this article briefly examines the global network of Catholic pro-life enterprises before focusing on one case study of the US Right exporting its antiabortion ideas and strategies to Ireland. The second part focuses on exchanges between Russian and American abortion opponents. This transnational relationship was also developed with the purpose of "protecting" women from abortion, as in Ireland. In addition, it features a temporal element, a sense of time running out, which resembles antiabortion militancy with white supremacist underpinnings. Arguing that outlawing abortion is necessary to avoid losing political and cultural dominance, some Russian antiabortionists reveal how their devotion to women is undergirded by white supremacist fears and ambitions to expand their political power across national boundaries. Such militant stances against abortion, as opposed to the global pro-life movement, have increasingly embraced a nonrationalist discourse, as we see in the US context, which comprises the final third of my analysis. This discussion examines how militant antiabortionists in the United States reject the goal of incremental legislative reform and continue a long-standing rhetorical strategy of what we now call "fake news."

\section{Rights-based rhetoric in Ireland}

Many US-based efforts to spread antiabortion messages abroad feature prolife and right-to-life rhetoric. ${ }^{1}$ Right-to-life arguments are a rationalist dis-

\footnotetext{
${ }^{1}$ In Killing for Life, I distinguish between right-to-life rhetoric and pro-life culture to show that different notions of equality and creation came into play as cultural conservatism began to
} 
course seeking to secure rights, through legislative reform, for the variety of products of pregnancy that have been reified as "the unborn," "the preborn," or prenatal "life itself." Despite doctrinal and denominational differences among religious stances against abortion, right-to-life rhetoric emerged in the 1960s and 1970s as a means to consolidate antiabortionists. We can see attempts to promote the right-to-life stance abroad as part of a larger effort to export right-wing Christianity throughout the second half of the twentieth century, when many Christian conservatives shifted from missionary work to politics (Hardisty and Berlet 2014). The variety of Roman Catholic organizations devoted to international action include Human Life International. Founder Paul Marx was explicit in his anti-Semitic apocalypticism, which derided "pro-abortion Jews" and the "pro-abortion medical professors who are Jewish" as "death peddlers" who were ushering in a "new holocaust" against "the unborn" (in Mason 2002, 172). Another prominent Catholic organization is the Apostles of Jesus, whose work in "more than 30 dioceses in Uganda, Kenya, Tanzania, Sudan, South Africa, Djibouti and Ethiopia” carries on a colonialist legacy of "civilizing" the supposed barbaric sexuality of the so-called Dark Continent (Hardisty and Berlet 2014). Examining recent antiabortion work in Ireland illustrates how US-based efforts to create a global pro-life network rely on rationalist discourse, embrace the state as an ally, and aim primarily for legislative reform seeking to criminalize abortion or reduce access to it.

In 1983, Ireland passed a constitutional amendment (the Eighth Amendment, or Article 40.3.3) that quintessentially asserted a right-to-life argument: "The State acknowledges the right to life of the unborn and with due regard to the equal right to life of the mother, guarantees in its laws to respect, and, as far as practicable, by its laws to defend and vindicate that right." ${ }^{2} \mathrm{Op}$ position ensued over the years, and by 1992 the Supreme Court recognized

\footnotetext{
dominate in the last quarter of the twentieth century (Mason 2002, 9-45). This historical and discursive shift reflects what, at the turn of the millennium, scholars such as Linda Kintz (1997) called "the emotions that matter" and what scholars currently explore as affect. Killing for Life also elucidates how different kinds of pro-life writing exploit the indeterminacy of the term "life" instead of agreeing on an absolute meaning of it (Mason 2002, 162-71, 186). This embrace of indeterminacy, relativism, and equivocation, which conservatives previously rejected as a liberal pathology while expounding the virtues of absolute truth, is found in other elements of right-wing literature in America (Mason 2018) and presages the postfactualism of the Trump era (Parker, Meyer, and Buckley 2019).

${ }^{2}$ Eighth Amendment of the Constitution Act 1983 (Ir.), http://www.irishstatutebook.ie /eli/1983/ca/8/enacted/en/html.
} 
women's health as an important factor to consider. That decision was further condoned and codified in 2013 with the Protection of Life during Pregnancy Act, which kept abortion a crime unless the pregnant woman's life was at risk. In 2017, a Joint Committee on the Eighth Amendment continued this line of argument and recommended that Article 40.3.3 be repealed in a referendum planned for 2018. As the right-to-life argument swung in favor of the right of women to terminate pregnancies that might kill them if continued, abortion opposition began to focus, too, on women's health, a tactic that never lost sight of the rationalist approach of swaying lawmakers and voters. In May 2018, Ireland overturned the Eighth Amendment in a historic victory for abortion rights advocates. Consequently, Ireland became aligned more than ever with the liberal-secular consensus of Western countries, even as "elsewhere that consensus is under sudden strain and threat" (Douthat 2018).

Reports about the 2018 referendum on the Eighth Amendment illuminate how US antiabortionists sought to influence Irish voters. According to the New York Times, American youth funded by antiabortion organizations and professional "pro-life" advocates traveled overseas to sway people in public and in person. The arguments deployed avoided religious sentiment and instead turned “to arguments that abortion harms women's health. They are also turning to social media tools" (O'Loughlin 2018). There were online campaigns that strived to subvert Ireland's rules against political advertising on television and radio. A Washington, DC-based "firm that has developed apps for the Trump campaign, the National Rifle Association, the Republican National Committee and Vote Leave," which encouraged the British to exit the European Union, was also retained by Ireland's antiabortion campaigns. Those who tracked the ads recognized that the opportunity to influence voters through unregulated social media represented a "serious vulnerability in our democratic system” (O'Loughlin 2018). The result was an onslaught of Facebook ads in favor of retaining the Eighth Amendment. Most of the advertisers were from the United States; the names of the organizations and their slogans attest to the focus on opposing abortion to protect women and mothers. For example, "one of the American groups is called Expectant Mother Care," and the American antiabortion organization Live Action created a hashtag \#WomenBetrayed to campaign against the repeal (Provost and Whyte 2018). This level of influence by US antiabortionists deploying pro-woman rhetoric in Ireland was a digitalized acceleration of decades of importing American antiabortion personnel who increasingly played the woman card.

As the Protection of Life during Pregnancy Act was being debated in Ireland, abortion foes hosted a 2012 International Symposium on Maternal 
Health, thereby emphasizing women's well-being instead of saving fetuses. ${ }^{3}$ One result was the creation of "The Dublin Declaration on Maternal Healthcare," which argues that there is never any medical reason that justifies abortion. Based on "junk science," this declaration contradicts the established worldwide data that demonstrate how maternal mortality rates go up when abortion is criminalized (Morgan 2017). Moreover, the Dublin Declaration has been a boon to the "global expansion and consolidation of Catholic health care facilities" and has proven effective in Latin America, especially in El Salvador and Chile (Morgan 2017). Another result of the 2012 international symposium was the importation of American speakers, one of whom, Priscilla Coleman, writes academic studies perpetuating the idea that abortion psychologically harms women. As suspect as the Dublin Declaration on Maternal Healthcare, Coleman's studies rely on medical misinformation and flawed methodology to achieve their results (Dreweke 2012). Coleman returned to Ireland in 2017 to speak at a conference hosted by Human Life International. In addition to Coleman, the conference featured Abby Johnson, the former director of a Texas Planned Parenthood clinic who decided that she was pro-life. Throughout the process, American women were at the forefront of fending off efforts to repeal the amendment criminalizing abortion in Ireland.

On the one hand, these US speakers were following a well-trod path made by American abortion foes to Ireland and back. Americans United for Life (AUL) boasts about their impact on Ireland beginning decades ago: "In 1979, AUL played a pivotal role in amending the Irish Constitution to protect life by precluding abortion." Later, when Ireland's "pro-life constitution was challenged before the European Court of Human Rights," AUL again "served as a consultant" and continued to do so throughout the efforts to rescind the Eighth Amendment $(2018,471)$. In addition, Joe Scheidler of Prolife Action League has long been influential in exporting militant tactics to Youth Defence-Ireland's major antiabortion organization, which has been linked to far-right movements in Europe-by speaking at its conferences and bringing its speakers to the United States (Marty 2015; O'Loughlin 2018). Scheidler's tactics promote the kind of aggressive behavior that ushered in the "direct action" militancy that emerged in the United States in the 1980s and 1990s. His book Closed: 99 Ways to Stop Abortion (1985) remains a how-to manual for militants who want to drive reproductive health care workers out of business through harassment and deter women seeking abor-

\footnotetext{
${ }^{3}$ Protection of Life During Pregnancy Act 2013 (Act No. 35/2013) (Ir.), http://www .irishstatutebook.ie/eli/2013/act/35/enacted/en/print.
} 
tions through scare tactics and shaming (Marty 2015). On the other hand, Coleman and Johnson, as women, diminished the reputation the pro-life movement has for such shaming and misogyny. Their claim to oppose abortion for the sake of women's protection and well-being represents the way today's rationalist right-to-life argument portrays women as victims of an abortion industry.

Abby Johnson's work illustrates this point. Johnson was associated with Planned Parenthood for eight years, first as a volunteer clinic escort and ultimately as the director of a clinic in Texas. She made headlines when she very publicly converted to the "other side," a conversion that coincided with a tactic called "40 Days for Life." Presented as an innovation in prayer service, the forty days of prayer, which stationed at least two antiabortionists outside the clinic where Johnson worked every hour of the day for over a month, was an established tactic of surveillance and intimidation (Johnson 2010; Saurette and Gordon 2016, 179-80). The relentlessness was especially intimidating because just four months earlier, on May 31, 2009, Kansas physician George Tiller was murdered by an antiabortionist with connections to both Operation Rescue and the 1990s-era militia movement. In the midst of these forty days of clinic harassment, according to her 2010 book Unplanned, Johnson was asked to help a physician in her clinic with an ultrasound-guided abortion. Viewing this abortion was a revelation and the catalyst for her conversion, Johnson maintains, which seems incredible given her position as the director of the clinic and given that ultrasounds prior to abortions are standard procedure (Marcotte 2010). This dramatic response to the ultrasound echoes the gothic description offered in The Silent Scream, a 1984 film that used the then-novel technology of ultrasound to show "the truth" of abortion (Valerius 2013). Johnson also maintains that her gradual “discovery of Planned Parenthood's revenue agenda" (121) and its "money-first attitude toward abortion, especially late-term abortions" (121) led to her claim that women are "victims" (137) of proabortion profiteers who seek to exploit them for financial and political gain.

Johnson's Unplanned resonates resoundingly with Won by Love: Norma McCorvey, Jane Roe of Roe v. Wade, Speaks Out for the Unborn as She Shares Her New Conviction for Life, the 1997 memoir detailing McCorvey's very public conversion to pro-life Christianity after working at an abortion clinic. According to the books, both women experience a miraculous conversion after antiabortion Christians opened offices adjacent to the clinics where they worked. Both authors make the same claims about the so-called abortion industry: it is duplicitous, unclean, profiteering, and jeopardizes women's health (McCorvey 1997; Johnson 2010, 2018). Johnson's story follows a rhetorical strategy that goes back to the 1970s - as Haugeberg's (2017) 
work on women against abortion attests — but that was systematized in the 1990s.

Saurette and Gordon $(2016,299)$ trace the proliferation of pro-woman rhetoric to the mid-1990s, overlooking an important source. In 1992, Life Dynamics founder Mark Crutcher promoted the idea of appearing to work on behalf of women while opposing abortion in an influential underground manual called Firestorm: A Guerrilla Strategy for a Pro-life America. He writes that abortion rights advocates "are evidently so accustomed to our arguments being focused only on the unborn baby, for us to voluntarily talk about the woman catches them totally off-guard" (75). Consequently he recommends that "legislation should be sold as 'pro-women' and/or 'consumer protection' legislation" (59). Moreover, Firestorm, which lays out a legislative and activist plan for all fifty states, insists that "in all cases make sure the person delivering the message [in court] is female" (70). Crutcher's Firestorm and McCorvey's memoir indicate that Johnson's memoir and her conversion are reboots of tactics first deployed systematically in the 1990s.

It is this approach to opposing abortion-the tactic of supposedly protecting women against deceptive exploiters - that Johnson lent to Irish efforts to retain the criminalization of abortion in December 2017 (Mac Donald 2017). At a conference meant to bolster support for retaining the Eighth Amendment, she said, "abortion can never be safe," either for the "unborn children" or "their mothers," thereby reinforcing the message that Priscilla Coleman had voiced just months earlier at a Human Life International conference in Dublin on the supposedly deleterious effects of abortion on women (HLI Staff 2017). The messages exported by Catholic Americans Abby Johnson and Priscilla Coleman function to expand the antiabortion rights-based rhetoric from the "unborn" to women.

In the face of unprecedented support for repealing the Eighth Amendment, this appeal to women as health-care consumers blends easily with the traditional association of women as mothers of the nation. Throughout the twentieth and twenty-first centuries, according to historians such as Cara Delay, Irish women have experienced a loss of national belonging when they cross the border to obtain an abortion. The continuity of women's experience in Irish history is exploited by the purportedly pro-woman approach delivered by Coleman and Johnson on behalf of Human Life International — an approach that could only exacerbate women's feeling alienated from their country "because they chose abortion over the national ideal of motherhood" (Delay 2019). This international traffic in gender-based antiabortion work preserves and promotes Irish nationalism, embracing the state and lawmakers at the expense of women. It also reflects the femonationalism operating in France, Italy, and the Netherlands - a form of na- 
tionalism that forwards right-wing agendas in the name of women's rights (Farris 2017).

Especially in its sustained formulation of the abortion debate as a "clash of absolutes" (Tribe 1992), the international efforts by US-based abortion opponents resemble femonationalism, which relies on a Manichean division of foes and forecloses any intersectional approach to abortion as a matter of broader reproductive health justice. According to Farris, "by encouraging a rhetoric of division, or a Manichean splitting of the political and ideological debate into one counterposing 'Us' (white, European, western, Christian, civilized, 'women-friendly') to 'Them' (nonwhite, non-European, non-western, Muslim, un-civilized, misogynist Others), right-wing nationalist parties have everything to gain" $(2017,8)$ This narrative framing so currently evident among right-wing nationalists in a variety of countries has structured abortion politics for decades, especially in its racialized rhetoric. ${ }^{4}$

As previous research demonstrates, the Manichean narrative framing of abortion politics reveals the ideological intersections among antiabortion militants, far-right agitators (such as the militia movement and organized white supremacists), and secular or religious right-to-life organizations (Mason 2002, 99-157). Through this framing of absolute opponents, antiabortion writings from all factions of pro-life politics promoted the fight against abortion as an apocalyptic narrative that operated in secular as well as sacred registers but found its most vociferous manifestation in antiabortion violence and "pro-life" murders (Mason 2002). These murders were often imbued with anti-Semitism and undergirded by racialist sentiment (Mason 2002). Many of the US abortion militants who committed homicide in the name of "life" were Holocaust deniers even as they decried the so-called holocaust of the unborn, which they also likened to slavery and genocide, as we will see below. The racialist underpinnings of their writings and speech were bound

\footnotetext{
${ }^{4}$ In considering the cultural work of antiabortion politics as a matter of narrative, I follow the work of narratologists who see narrative as a system of meaning rather than a formal structure. This approach is different from (but often compatible with) literary scholars who consider antiabortion material in light of generic conventions of a particular kind of story, such as the gothic, and sociologists who consider antiabortion rhetoric as social scripts or narrative framing (e.g., Valerius 2013; Saurette and Gordon 2016, 271-91). In addition to these approaches, a narratological approach recognizes the malleability and variability of narrative as a poststructural system of meaning (Roof 2015) as well as the affective articulation of identificatory subjectivities that result when cultural logics interpellate readers as players in social dramas (Currie 1998; Mason 2002). In other words, I consider the affective "ability of narrative to forge rather than simply reflect agency," social identity, and political action (Warhol and Lanser $2015,6)$.
} 
up with the apocalyptic narrative that structured the issue not only as a Manichean conflict between absolute enemies but also as a matter of running out of time and racing toward a cataclysmic end. This apocalyptic sense of antiabortion discourse has been exported from the United States to Russia since the mid-1990s.

\section{Running out of time in Russia}

Unlike Ireland, where politics have been so entrenched in Catholicism that women have consistently perceived terminating pregnancies as tantamount to terminating their national belonging, Russia has a complicated past regarding abortion. The Soviet Union led the world in decriminalizing abortion in 1920. A little more than a decade later, however, the Soviet government banned it. By 1955 it was decriminalized again. But the conditions under which women terminated pregnancy in the mid-twentieth-century USSR were awful: "Considering abortion an undesirable social practice, state officials gave no thought to women's comfort during the procedure," which sometimes was done without anesthesia, without privacy, and with the attitude that women need to suffer for relinquishing motherhood (Rivkin-Fish 2013, 573). Unlike the American decriminalization of abortion in 1973, Nikita Khrushchev's relegalization of it in 1955 was not so clearly a win for Soviet women, especially since it was the primary method of fertility control, as barrier methods of contraception were not produced or encouraged. Consequently, unlike abortion in the United States, abortion in Russia was nearly a universal experience for women, a necessity rather than the choice of self-determined women (Rivkin-Fish 2013; Luehrmann 2016).

Much of the discourse determining these changes focused on demographics. Anthropologist Michele Rivkin-Fish $(2003,290)$ has traced the subtleties in language and argument regarding birth rates to provide a genealogy of the "demographic crisis" in Russia. Throughout the twentieth century, "fertility analysis has been used in national political struggles in Russia" (289), and anxiety over a diminishing birth rate returned with a vengeance in the 1990s, when attempts to curtail access to abortion resumed with new determination as a "postsocialist panic" (293). Especially after the Soviet collapse and the ascendance of the Russian Orthodox Church, imports of US antiabortion tactics and rhetoric have aided Russian attempts to thwart abortion as a supposed cause of demographic demise: "From the beginning of the 1990s, Russian nationalists seized on abortion and contraceptives as insidious practices contributing to the nation's low fertility and rapidly decreasing population" (Rivkin-Fish 2013, 573; see also 2003). 
Rivkin-Fish's analyses do not detail how the global antiabortion movement, led by the United States, provided ongoing support since the 1990s.

Beginning in 1995 with the founding of the World Congress of Families in Moscow, right-wing US evangelicals have worked to persuade Russians to adopt tactics such as mandating waiting periods ranging from forty-eight hours to a week and counseling sessions that include ultrasounds (Kishkovsky 2011). These mandates entail familiar scare tactics such as claiming that abortion causes infertility. While there has been an increase in "American style pickets of abortion clinics" and "graphic web sites, posters and leaflets [that] are supplemented with sweeping references to Russian history," the most insidious of innovations has been the Russian adoption of what we in the United States call "crisis pregnancy centers" (Kishkovsky 2011). These centers have emerged in Russia as places to support women by providing counseling, temporary housing, and sometimes job training (Parogni 2016). But like their US counterparts, their offers of aid, comfort, training, or donations come with scare tactics designed to sway the woman not to terminate her pregnancy and designed to look like scientific evidence when it actually is biased information, often delivered by psychologists paid for with antiabortion money (Parogni 2016; Haugeberg 2017, 45-49).

These tactics reflect the pro-woman campaigns in Ireland and the United States. But who is paying for them? The financial and institutional links among American and Russian antiabortionists demonstrate a transnational web of networking that makes it difficult to tell who is profiting from the political power or money transfers that circulate through churches, nongovernmental organizations, and nonprofit antiabortion organizations. Especially through the World Congress of Families (WCF), some of the "most powerful organizations in America's religious Right, including Concerned Women for America, Focus on the Family, and Americans United for Life," have brought their homophobic and antiabortion influence to Russia (Levintova 2014b, 2014c). The WCF was founded in 1995 by Allan Carlson, an American professor and manager of the Howard Center for Family, Religion, and Society in Illinois, and Anatoly Antonov, a sociologist specializing in demographics at Moscow State University. Their collaborations and yearly WCF demographic conferences helped shape late twentieth- and early twenty-first-century Russian attitudes and policies that opposed abortion under the guise of protecting women.

In the first decade of the twenty-first century, two initiatives - the "maternity capital program" that provided "financial bonuses to women giving birth to two children or more" and guidelines on how mandated preabortion counseling was to be administered-emphasized the purported harms of abortion to Russian women (Parogni 2016). Maternity capital harkened back 
to "socialist ideals that the state should bear some of the burden of raising children" (Rivkin-Fish 2013, 585; see also Rivkin-Fish 2010), but it paradoxically provided material support only if the woman increases her family's material need by having another baby. Groups such as the Sanctity of Motherhood Program and the Patriarch's Commission on the Family and Protection of Motherhood and Childhood carried forward the idea that fighting abortion should be seen as a matter of protecting women. But these staterun programs did not provide funds for preabortion counseling, and the maternity centers that were mandated to offer such counseling consequently relied on outside money tied to "deeper collaboration" with anti-abortion groups, some from the United States (Parogni 2016).

In the second decade of the twenty-first century, those collaborations increased. In 2010, the managing director of the WCF, Larry Jacobs, "held dozens of meetings with Russian policymakers and leaders" (HRC 2015, 12), including a Russian antiabortionist who the following year visited Dallas, Texas, as guest of an oilman with ties both to Russia and to Koch Industries, the influential US oil and gas company (Kishkovsky 2011): “A package of anti-abortion laws - the first new anti-choice laws in Russia since the fall of the Soviet Union" followed in 2011, accompanied by companion legislation outlawing gay "propaganda” (HRC 2015, 13). Policy makers responsible for this legislation met multiple times with WCF's director Jacobs. One of them served on the planning committee for the eighth WCF conference, which was rebranded after Russia annexed Crimea and the United States imposed "economic sanctions against many Russian leaders, including two major backers of WCF" in 2014 (HRC 2015, 14; see also Levintova 2014a).

By 2015 symposia focusing on fetal pain and maternal trauma featured American scientists such as Maureen Condic, a professor of neurobiology at the University of Utah, and attracted attendees from twelve different countries and a hundred cities (Jalsevac 2015). A year later, in 2016, antiabortionists convened a "For Life festival, an annual gathering of Russian activists and international guests involved in the global fight against abortion" (Parogni 2016). As a result of this convention, For Life became an umbrella organization for more than four hundred antiabortion entities, consolidating power to push for a ban on abortion and to persuade women to reject the practice of abortion until it is banned (Parogni 2016). Russia's pronatalist nationalism relies on a transnational movement of US funds, personnel, and tactics.

In light of the investigations into Russian interference into the US presidential election of 2016, we should ask how much antiabortion organizations in Russia and the United States are part of the transnational finances 
that shape oligarchies, right-wing movements, and the Trump-Pence administration. Three years before Trump shocked the American public by consistently praising Vladimir Putin while campaigning, WCF managing director Larry Jacobs explained that "for 70 years we fought the communists, and some conservatives still associate Russia with a far left communist country, when the reality is, among the more powerful nations, Russia is one of the most conservative countries in the world" (in Young 2013). Claiming "Russia could be a great ally for conservatives, on issues like defending the family, abortions, even strengthening marriage and promoting more children" (Young 2013), Jacobs and WCF founder Allan Carlson have "built strong relationships" with influential Russian oligarchs and policy makers, one of whom operated in Italy as a representative of the WCF, rubbing elbows with prominent far-right members of the Netherlands' Party for Freedom, France's National Front, and Italy's Northern League (Shekhovtsov 2018, 180). In Italy, politician Luca Volonte, who received the "Family and Truth" award from Americans United for Life, was charged with laundering bribes through various organizations, including an antiabortion organization that supported Trump strategist Steve Bannon's “video address inside the Vatican" (Feder and Nardelli 2017). While issues of money laundering through pro-life organizations remain unproven, the pronatalist messaging shared by far-right populists and transnational antiabortionists consistently strikes an apocalyptic tone and fuels the white supremacism of the global Right.

In Russia, partners of WFC such as Archpriest Dimitri Smirnov, the top Orthodox official and chairman of the Patriarchal Commission on Family Matters and the Protection of Motherhood and Childhood, has sounded an alarm of apocalyptic proportions. "There is very little time left until the death of the entire Christian Civilization," he claimed. "Several decades," he predicted, "perhaps 30 years, well, maybe in Russia it will last 50, no longer” (CBN 2017; MEMRI 2017). Structuring the political and moral dilemma of abortion in this way is a means of manufacturing a sense of time running out, creating a sense of urgency to act, lest the nation be lost. But lost to what or to whom?

Because atheism was state policy in the Soviet Union, the scare tactic of saving the soul of the nation before the return of Jesus Christ was unlikely to work as it has among evangelicals in the United States. But since the 1990s, that atheism has come under fire as President Putin has overseen a "clericalization of Russia" in which speaking out against religion or religiosity has been outlawed (Chikov 2017). The exact content of the apocalyptic, nearly no-time-left narrative that structures US pro-life politics is unlikely to influence Russian people, but the deployment of its temporality appears to 
be highly effective. The narrative in Russia is therefore not that God will lift His veil of protection if citizens do not stop the "national sin" of abortion, as it has been among US evangelicals. Instead, the contemporary Russian antiabortion narrative is about losing the nation to those who may outbreed the Russians; the apocalyptic narrative asserts that demographic decline, brought about by abortion, will usher in a larger Muslim population and the end of white civilization. During pro-life conferences sponsored by the WCF in Moscow, "the high birth rate among Muslims in Russia was spoken of with some awe, both as a threat and as something to emulate" (Parogni 2016). When we recall that the WCF was founded by a couple of professors whose academic interest is demographics, we see that the fear of losing cultural and political dominance has been an issue from the very beginning of Russian-US antiabortion collaboration. In 1995, Antonov and his colleagues were eager to discuss “Allan Carlson's work on demographic changes in the United States - work that claims feminism and homosexuality have led to population decline, precipitating a crisis of the American family. Antonov and Medkov saw the same thing happening in postcommunist Russia and felt they had much to learn" (HRC 2015, 7). What they learned, and taught to others, was how to shift a whole country from leftist to right-wing perspectives on abortion. Putin seems to have heard this apocalyptic alarm of demographic demise; "Putin's next target is Russian's abortion culture," according to a 2017 report (Ferris-Rothman 2017).

Ethnographic studies illuminate what this targeting of abortion means for Russian women. Depicting women as victims of abortion as well as sinners, antiabortion activists in Russia have deployed the idea of postabortion syndrome, which underscores the notion that women have suffered exploitation by the state as well as having perpetrated state violence against the unborn (Luehrmann 2016, 115). But in this formulation, opposition to abortion is not argued in terms of murdering babies because historically the unborn in Russia have not been imbued with individual, inherent rights, as the more (classically liberal) right-to-life arguments insist in America (Mason 2002, 16-17; Luehrmann 2016, 107). Because "the unborn foetus as a rights-bearing person did not enter Soviet discourse," the unborn in Russia are more comparable to the unborn of pro-life conservative nationalism; they represent the collective future of a nation (Luehrmann 2016, 107; 2017; Mason 1999; 2002, 17-21). Russian women's experiences of expiating abortions reveal that "anxieties about demographic development turn unborn children into symbols of a desired future" (Luehrmann 2016, 116). And, based on how male Russian antiabortionists talk about it, the collective Russian unborn can also symbolize an undesired future, one that is too Muslim. 
Constructing a pronatalist, pro-woman nationalism that argues against abortion in the name of women's rights, US-Russian collaborators have created an antiabortion force that is also anti-Islamic. Saving the so-called unborn becomes tantamount to saving women becomes tantamount to saving the nation from Muslims lest "Russians . . . become an ethnic minority in their own vast country" (Kishkovsky 2011). This widespread fear of becoming an ethnic minority has characterized some antiabortion militants in the United States, too (Mason 1999; Ferber 2003). In fact, we can see how antiabortion rhetorical and tactical innovations from the 1990s set the political stage for a postfactual politics (Parker, Mayer, and Buckley 2019) and how they have been updated to avoid overt misogyny, reject rationalist argument, rail against the state, and foment right-wing populism that transcends national boundaries.

\section{Postfactualism in the United States}

Like right-to-life efforts in Ireland and apocalyptic pronatalist campaigns in Russia, antiabortion work in the United States has increasingly adopted a prowoman approach since the 1990s. But the pro-woman approach among militant abortion foes in the United States eschews rights-based rhetoric and instead embraces a postfactual discourse, in which "a lesser degree of truthfulness" is accepted and effective due to its affect-its emotional appeal (Parker, Mayer, and Buckley 2019, 122). The pro-woman approach that militant antiabortionists in the United States employ actually revives tactics and conspiracies that were seen as extreme in the 1990s: namely, the idea of fighting abortion through "rescue" and the racial rhetoric of abolishing abortion through direct action.

Consider, first, the pro-woman approach of the renewed rescue tactics in the United States. In the 1980s and 1990s, the rescue movement was a militant attempt to physically block people's path to clinic doors so they could not enter the facility to perform or obtain the abortions scheduled for the day. Antiabortionists considered their success a matter of rescuing the unborn. Blockades ranged from people linking arms and standing in the way, to parking cars in front of clinic doors, to mobilizations of hundreds of antiabortionists, the sheer number of whom was intimidating to clients, not to mention the shaming hostility that they faced from the jeering crowd of predominantly white Christians reminiscent of lynch mobs. The 1994 Freedom to Access Clinic Entrances (FACE) act quashed these tactics. Recently, however, the renewed rescue movement has turned from seeking to rescue the unborn to rescuing the women in the clinic. Instead of blocking the doorway, female antiabortion activists enter it like clients do and distribute roses to the 
actual clients in the waiting room with the hope of dissuading them from going through with the scheduled procedure (Marty 2017). Once in, they refuse to leave, claiming a right to stay because they are not blocking entrances. This pro-woman approach to disrupting the operation of abortion clinics attempts to skirt trespassing laws and FACE.

A companion effort and more militant revival of the rescue movement was the July 2017 attempt to close Kentucky's sole remaining abortion clinic, the EMW Women's Surgical Center. A male-dominated collaboration of antiabortion organizations (including Missionaries to the Preborn, Operation Save America, and several local churches and groups) threatened not only to "ignore Roe" but also to break the FACE law, which they depicted as only one reason to disobey federal authority. ${ }^{5}$ This meant that hundreds came to EMW in hopes of physically blocking access and preventing workers and clients from entering. Ultimately, the antiabortionists could not prevail against a buffer zone ordered by a federal judge; the clinic stayed open with extra police protection against the weeklong antiabortion protest (Gandy 2017). Despite President Trump's responsiveness to antiabortion directives (Desanctis 2018), there was decidedly antigovernment sentiment among the antiabortionists gathered in Louisville, who vowed to abolish abortion and invoked a "doctrine of the lesser magistrate."

The doctrine of the lesser magistrate, derived from Calvinist belief, purportedly justifies illegal action to oppose abortion by citing precedents in American history. The doctrine argues that "when the superior or higher ranking civil authority makes immoral/unjust laws or policies, the lower or lesser ranking civil authority has both a right and duty to refuse obedience to that superior authority. If necessary, the lesser authorities may even actively resist the higher authority" (Trewhella 2013). In 2013, Matthew Trewhella, founder of Missionaries to the Preborn, self-published The Doctrine of the Lesser Magistrates: A Proper Resistance to Tyranny and a Repudiation of Unlimited Obedience to Civil Government. Months before the Louisville action, antiabortionist organizers met with pro-life Kentucky Governor Matthew Bevin and presented him with Trewhella's book: "Christians were remonstrating in Kentucky for months to encourage the state authorities to cross a line, be brave, and defy the lawless, corrupt, and unconstitutional ruling of Roe vs. Wade" (Thomas 2016). Thus, the organizers attempted to provide state officials with a rationale to defy, and to let them defy, federal laws in order to oppose abortion by impeding access to the clinic.

\footnotetext{
5 "Ignore Roe" was one of the slogans featured throughout the national event in Louisville, Kentucky, organized by Operation Save America in 2017. The slogan appeared on t-shirts sold by the organization: http://store.operationsaveamerica.org/product-p/such-time.htm.
} 
During the Louisville siege, Operation Save America also reached out to police as state officials, hailing them as lesser magistrates. Writing directly to law enforcement officers, leader Rusty Thomas (2016) argued that their loyalty as officials of civil government rests foremost with God. Thomas also appealed to officers' sense of being "targeted" as a result of recent campaigns to halt fatal police action against unarmed African Americans. With thinly veiled references to the Black Lives Matter movement, the open letter to police praised "THE THIN BLUE LINE that separates the criminal element from society." Thomas opined, "Anarchy runs rampant while government tyranny grows. Our nation stands in awkward amazement as violence, carnage, terrorism, and massacres are becoming a common everyday experience in our nation. To our horror, this violence has now targeted our law enforcement agencies" (2016). In this appeal, Thomas draws a distinct line between the police and the tyrannical federal government, presumably in hopes that police themselves would defy — or let the antiabortionists defyfederal law.

Couched in historical examples of states' uprisings against supposed federal tyranny, Trewhella's Doctrine of the Lesser Magistrates is similar in purpose and tone to the Defensive Action Statement circulated in the 1990s (Trewhella 2013). Penned by Paul Hill, who was later convicted of murdering a physician and a clinic escort in 1994, the Defensive Action Statement was a declaration by antiabortionists who agreed that homicides were justified if the intention was to oppose abortion (Risen and Thomas 1998, 347). Trewhella was a signatory of the Defensive Action Statement in 1994.

Another prominent feature of the Louisville siege was the racialist rhetoric of abortion abolitionism. Founded by young white men, Abolish $\mathrm{Hu}-$ man Abortion is touted as the new vanguard in opposing abortion (Carmon 2014). Its founders protest what they see as an incrementalist approach of undoing women's rights via regulatory legislation. To challenge the pro-life establishment, Abolish Human Abortion unapologetically appropriates the historical plight of enslaved Africans in America and claims to be pro-woman. Adopting the language of social justice as a means to thwart racial oppression, the campaign deploys a claim of abortion as black genocide, invoking the historical trauma of people of color who have endured centuries of scientific and medical racism. The antiabortion movement has for years attempted to win support from African Americans with materials in different media, including comic books, video magazines, memes, so-called documentaries, campus tours, and bus tours (Joyce 2010). This race-based "scare tactic," as Kathryn Joyce (2010) has called it, becomes increasingly prominent when racial politics are important to electoral races. 
Beyond elections, the deployment of a specter of genocide should be seen as part of a global effort to curtail abortion rights and demonize women of color. Jennifer Denbow has demonstrated this in her analysis of abortion bans proposed to stop terminations based on the race or sex of the fetus. Even as they disavow eugenics, "supporters of race- and sex-selective abortion bans paradoxically draw on and reproduce the notions of national purity and civilization that undergirded eugenic policies" (Denbow 2016, 605). Depicting abortion as slavery, these bans are deemed necessary in order to uphold the national culture and values of racial and gender equality: "Women of color, therefore, emerge as a threat to the nation in their capacity to perpetuate antiAmerican values and, as potential reproducers and carriers of innocent fetal life, as essential to nation building" (605). Likewise, Asian women are depicted as the perpetrators, rather than the victims, of reproductive control. Miriam Yeung, the executive director of the National Asian Pacific American Women's Forum, writes about this trend in response to the criminal cases involving Purvi Patel and Bei Bei Shuai, who were prosecuted for alleged feticide in the state of Indiana in 2013 and 2011. These two cases signal a growing criminalization of pregnant women, and Patel and Shui are among the hundreds of women who have been arrested due to pregnancies that have gone awry (Paltrow and Flavin 2013). Yeung states that cultural misinformation and unsubstantiated "stories of infanticide in India . . . and gender-based abortions in China . . . are influencing legislation and courtrooms in the United States. As a result, states are adopting racially biased 'sex-selective abortion' bans, and laws like feticide, which were intended to protect pregnant women, are being used to criminalize immigrants and Asian Americans" (Yeung 2015; see also Mohanty 2012; Shanghai Daily 2014). Thus, allegations of "gendercide" have gone hand in hand with claims of abortion as genocide, all of which boil down to blaming the victims of reproductive injustices - women of color in the United States and globally.

Blaming the victim also comes into play with abortion-as-holocaust memes, which are paradoxically based on long-standing anti-Semitic tropes. Claims of abortion as a holocaust have inspired the most lethal abortion foes who took aim at doctors in the 1990s. Murderers who killed Dr. John Bayard Britton and his escort James Barrett in 1994, killed and maimed Alabama clinic workers in 1998, and fatally shot Dr. Barnett Slepian in 1999 all believed they were halting a holocaust. ${ }^{6}$ This was especially ironic given that Dr. Slepian had just

${ }^{6}$ The perpetrators were Paul Hill, Eric Rudolph, and Charles Kopp, each of whom repeated racialized, apocalyptic rhetoric that situated themselves as defenders against a "holocaust" of babies, not Jews. 
returned to his home from synagogue before being gunned down in his kitchen. The perpetrator in Alabama had written a high school essay about how, he claimed, the Nazi Holocaust of Jews was a hoax. While it may defy common logic, Holocaust denial is paradoxically often an unspoken assumption - and other times a blatant component - of claiming that abortion is a holocaust (Mason 2002, 38-44, 171-76).

These racial and religious references to genocide, slavery, and the Holocaust are not mere comparisons (Mason 2002, 118-27). Rather, they serve to tell a story of human atrocities that lead up to abortion as an apocalyptic culmination of human depravation (Mason 2002, 114-18). Abolish $\mathrm{Hu}-$ man Abortion embraces and perpetuates this narrative in claiming, "the abortion holocaust exceeds all previous atrocities practiced by the Western World" (AHA 2017). The result is a generic diminishment (if not erasure) of actual historical persecutions based on religion, race, sexuality, and gender. Moreover, as with other right-wing discourses in which "history itself-the distinctiveness of its multiple stages - is irrelevant during a time of Manichean struggle between cultures" (Mihailovic 2015, 89), abolishing abortion becomes an epic battle not against actual people as historical agents but a "war with the entire worldview that makes abortion legal in the first place" (AHA 2017). Thus, the AHA's home page declares, "Every age has its evils. Every age has its abolitionists" (AHA 2017). This gamer-type declaration casts the political battle over abortion as a Manichean narrative and generic vision quest to quash evil.

In this theocratic vision quest, optics are all important. In sharp contrast to their older counterparts who shame women with Bibles held aloft, AHA activists style themselves as progressive hipsters, posturing as cool big brothers to younger kids they recruit at high schools, which they consider to be the front lines of the abortion wars, not clinics. Their posters, memes, and websites rely on well-crafted graphic designs resembling the aesthetics of tattoos. While their historical arguments comparing the medical practice of abortion to the economic system of slavery are questioned even by some antiabortionists (Van Maren 2014), the use of visual artifacts from nineteenthcentury abolitionist campaigns lends a veneer of historical authenticity to the comparison. Relying on pictorial assertion rather than historical fact of any relationship between antiabortion and antislavery campaigns, the AHA is deliberate in its choice of visual rhetoric (AHA n.d.). Just as it rejects the rightto-life approach because it is believed to invite incrementalism instead of a commitment to act to end abortion - "we are not pro-life" - the AHA rejects the soft-focus cuteness of baby images that populate "pro-life" materials. Instead, the AHA designed a pictorial icon that links the initials A H A in such a way that it resembles, in the eyes of some onlookers, the newer incarnations of swastikas that are proliferating among white supremacist 
groups (AHA n.d.). To some, the initials, assembled as a cross-hatched lightning bolt, resemble the German Wolfsangel (OllieGarkey 2012; AHA n.d.). To some, that is, the look of efforts to abolish abortion feels a lot like Nazism.

The AHA's optics of appearing to be pro-black, pro-woman, radically upstart, and hipster cool are thus also read as white supremacist. By updating and proliferating the racial message that abortion is a matter of slavery and genocide, white advocates of abolishing abortion do not always specify which racial groups are the target of these imagined racial attacks. In this way, antiabortionists who have rejected the goal of incremental legislative reform and rationalist arguments about the right to life have redesigned their look in ways that make them legible to a variety of factions of the Right. Much like the polo-shirted, khakied alt-right, which has shunned the white robes of the KKK and recrafted Nazi symbols into updated iconography, the AHA appears on the surface to be more progressive than its earlier counterparts. Especially in the digital age of social media, the control of optics determines whose narrative is replicated, read, followed, believed, and acted out. In other words, the control of optics determines whose news- fake or not-has the most impact.

Antiabortionists were at the forefront of fake news in the 1990s. Mark Crutcher, author of the underground manual Firestorm (1992), began producing an impressive oeuvre of faux documentaries in the 1990s and inspired a new generation of antiabortion video activists. A young female protégé of Crutcher's named Lila Rose has (in collaboration with James O'Keefe of Project Veritas) gone on to produce undercover video stings as part of her Live Action organization (Joyce 2012). Live Action's supposed exposé of Planned Parenthood's purported fetal trafficking in the summer of 2015 updated Crutcher's attempt to create panic about the supposed "harvesting" of fetal "body parts" for the black market back in 2000 (Mason 2002, 174). In 2014, the year before Rose's "video was released, only one pro-life activist threatened to kill or harm an abortion provider. In 2015, the year the video was released, the number of threats jumped to 94 , and a gunman killed 3 and injured 9 at a Colorado Springs Planned Parenthood" (Haugeberg 2017, 143-44). Like Rose's attempt to smear Planned Parenthood, right-wing efforts-led by Rose's collaborator, James O'Keefe - to smear the Association of Community Organizations for Reform Now (ACORN) contributed to the voter suppression that helped elect President Trump (Minnite 2012). While political entities have always relied on spin and propaganda of sorts, especially when it comes to elections, prolife faux documentaries that create moral outrage via supposed exposés and documentaries can influence elections. These faux documentaries can be seen as both a precursor to and a subgenre of the fake news that has proliferated in the era of Trump, whose lies epitomize postfactual politics. Like 
films by Citizens United that defamed Hillary Clinton, these faux documentaries opposing abortion embrace a postfactual discourse that depends on creating the feel of documentary film, historical analysis, and journalistic exposé without actual facts or logical arguments (Krzych 2016; Parker, Mayer, and Buckley 2019). The fact that a woman, Lila Rose, is one of the producers underscores the pro-woman trend that characterizes antiabortion work in the age of femonationalism (Farris 2017).

\section{Conclusion: Pro-woman rhetoric, femonationalist reproduction, and right-wing networks}

Ireland's recent fight to retain the Eighth Amendment demonstrates the transnational work by antiabortion women. Antiabortion travel to Ireland from the United States had its beginnings in the 1990s when policy and rhetoric shifted in a systemic way to centralize "the woman" and "the mother" rather than arguing on behalf of the fetus. Fighting to criminalize abortion as a matter of maternal health and of opposing the exploitation of women became a way for pro-life Irish women to assert their national belonging and their place as mothers of the nation. And so, as Farris says, "the current mobilization of gender equality and feminism as tools in the service of strengthening of nationalist and racist discourses should be regarded not simply as 'ideological cover,' in a negative and limited sense." Instead, it is important to see fighting against abortion in the name of protecting women as indicative of the roles that women play in the economic, political, and "material chain of production and reproduction" (Farris 2017, 182). Moreover, it helps illuminate the "cultural capital of victimhood" as it is bound up with populist nationalism, whiteness, and women (Chow 2002, 153-82). As the analysis of Russia demonstrates, opposing abortion to protect women is not merely a ploy by which right-wing misogynists seek to oppress women. Rather, it is a political goal inspired by and integrated with the fear of becoming an ethnic minority. Seeing themselves as victims of demographic demise while protecting women as victims of abortion, white Christians in Russia have worked to create right-wing networks in Europe and the United States. This cross-cultural look at antiabortion collaboration reveals a transnational traffic in tactics, personnel, and funds that fuels right-wing politics and ideology. We therefore ignore the transnational and intersectional aspects of antiabortion work at the risk of imperiling democracy around the world.

Department of Gender and Women's Studies

University of Kentucky 


\section{References}

AHA (Abolish Human Abortion). 2017. "International Coalition of Abolitionist Societies." http://abolishhumanabortion.com/international-coalition-of-aboli tionist-societies/.

n.d. "What Is the AHA Symbol For?" http://blog.abolishhumanabortion $. \mathrm{com} / \mathrm{p} /$ abolitionists-identify.html.

AUL (Americans United for Life). 2018. "Defending Life 2018." http://www.aul .org/wp-content/uploads/2018/01/Defending-Life-2018.pdf.

Balmer, Randall. 2014. "The Real Origins of the Religious Right.” Politico, May 27. https://www.politico.com/magazine/story/2014/05/religious-right-real-origins $-107133$.

Beauchamp, Toby. 2018. Going Stealth: Transgender Politics and U.S. Surveillance Practices. Durham, NC: Duke University Press.

Carmon, Irin. 2014. "Meet the Rebels of the Anti-abortion Movement." MSNBC, March 8. http://www.msnbc.com/melissa-harris-perry/meet-the-rebels-the -anti-abortion-movement.

CBN (Christian Broadcasting Network). 2017. "Orthodox Priest Warns Europe Will Turn Muslim in 30 Years, Russia in 50." May 16. https://wwwl.cbn.com /cbnnews/world/2017/may/orthodox-priest-warns-europe-will-turn-muslim -in-30-years-russia-in-50.

Chikov, Pavel. 2017. "In the Name of God: Atheists in Russia under Fire." Moscow Times, May 18. https://themoscowtimes.com/articles/in-the-name-of-god -atheists-in-russia-under-fire-op-ed-58025.

Chow, Rey. 2002. The Protestant Ethnic and the Spirit of Capitalism. New York: Columbia University Press.

Crutcher, Mark. 1992. Firestorm: A Guerrilla Strategy for a Pro-life America. Lewisville, TX: Life Dynamics.

Currie, Mark. 1998. Postmodern Narrative Theory. New York: St. Martin's.

Delay, Cara. 2019. "From the Backstreet to Britain: Women and Abortion Travel in Irish History." In Travellin' Mama: Mothers, Mothering, and Travel, edited by Charlotte Beyer, Janet MacLennon, Dorsia Smith Silva, and Marjorie Tesser. Bradford, ON: Demeter.

Denbow, Jennifer. 2016. "Abortion as Genocide: Race, Agency, and Nation in Prenatal Nondiscrimination Bans." Signs: Iournal of Women in Culture and Societv $41(3): 603-26$.

Desanctis, Alexandra. 2018. "How Have Trump's Pro-life Promises Held Up?" National Review, January 3. https://www.nationalreview.com/2018/01/donald -trump-abortion-pro-life-victories-year-one/.

Douthat, Ross. 2018. “The Irish Exception.” New York Times, May 19. https://www .nytimes.com/2018/05/19/opinion/sunday/ireland-abortion-amendment .html.

Dreweke, Joer. 2012. "Study Purporting to Show Link between Abortion and Mental Health Outcomes Decisively Debunked." Guttmacher Institute, March 5. 
https://www.guttmacher.org/news-release/2012/study-purporting-show-link -between-abortion-and-mental-health-outcomes-decisively.

Farris, Sara R. 2017. In the Name of Women's Rights: The Rise of Femonationalism. Durham, NC: Duke University Press.

Feder, J. Lester, and Alberto Nardelli. 2017. "This Anti-abortion Leader Is Charged with Laundering Money from Azerbaijan.” Buzzfeed News, April 26. https://www .buzzfeed.com/lesterfeder/this-anti-abortion-leader-is-charged-with-laundering -money?utm_term $=$.qrmlnQ5QE\#.qczqyoxoJ.

Ferber, Abbie L. 2003. Home-Grown Hate: Gender and Organized Racism. New York: Routledge.

Ferris-Rothman, Amie. 2017. "Putin's Next Target Is Russia's Abortion Culture." Foreign Policy, October 3. http://foreignpolicy.com/2017/10/03/putins-next -target-is-russias-abortion-culture/.

Gandy, Imani. 2017. "Judge: Anti-abortion Protesters in Kentucky Must Stay Out of Buffer Zone." Rewire News, July 21. https://rewire.news/article/2017/07/21 /federal-judge-orders-anti-abortion-protestors-kentucky-stay-away-buffer-zone/. Hardisty, Jean, and Chip Berlet. 2014. "Exporting Right-Wing Christianity.” http:// www.jeanhardisty.com/writing/articles-chapters-and-reports/exporting-right -wing-christianity/\#footnote-ref27.

Haugeberg, Karissa. 2017. Women against Abortion: Inside the Largest Moral Reform Movement of the Twentieth Century. Urbana: University of Illinois Press.

HLI Staff. 2017. "UPDATE: HLI Ireland Conference Forced to Move after Threats Rescheduled." Human Life International, September 22. https://www.hli.org /2017/09/venue-refuses-hosting-hli-event-after-receiving-threats/.

HRC (Human Rights Campaign). 2015. "Exposed: The World Congress of Families.” June. https://www.hrc.org/resources/exposed-the-world-congress-of -families.

Jalsevac, John. 2015. "Top Scientists Meet in Moscow, Tell Russian Government: Fetus Is Human; Ban Abortion." LifeSite News, July 15. https://www .lifesitenews.com/news/top-scientists-meet-in-moscow-tell-russian-government -fetus-is-human.-ban-a.

Johnson, Abby. 2010. Unplanned: The Dramatic True Story of a Former Planned Parenthood Leader's Eye-Opening Journey across the Life Line. Carol Stream, IL: Tyndale House.

- 2018. "How to Close Abortion Facilities from the Inside Out." Federalist, January 11. https://thefederalist.com/2018/01/11/close-abortion-facilities -inside/.

Joyce, Kathryn. 2010. “Abortion as 'Black Genocide': An Old Scare Tactic Reemerges.” Political Research Associates, April 29. http://www.politicalresearch .org/2010/04/29/abortion-as-black-genocide-an-old-scare-tactic-re-emerges /\#sthash.mTVux7bn.dpbs.

2012. "Lila Rose: A Sweet Face to Accompany Extreme Antiabortion Claims." On the Issues (Winter). http://www.ontheissuesmagazine.com/2012 winter/2012winter_Joyce.php. 
Kintz, Linda. 1997. Between Jesus and the Market: The Emotions That Matter in RightWing America. Durham, NC: Duke University Press.

Kishkovsky, Sophia. 2011. "Russians Adopt U.S. Tactics in Opposing Abortion." New York Times, June 9. http://www.nytimes.com/2011/06/10/world /europe/10iht-abortion 10.html.

Krzych, Scott. 2016. "Beyond Bias: Stock Imagery and Paradigmatic Politics in Citizens United Documentaries." Jump Cut, no. 57. https://www.ejumpcut.org /archive/jc57.2016/-krzychStockFootage/index.html.

Levintova, Hannah. 2014a. "Did Anti-gay Evangelicals Skirt U.S. Sanctions on Russia?" Mother Jones, September 8. https://www.motherjones.com/politics /2014/09/world-congress-families-russia-conference-sanctions/.

. 2014b. "How U.S. Evangelicals Helped Create Russia's Anti-gay Movement." Mother Jones, February 21. https://www.motherjones.com/politics /2014/02/world-congress-families-russia-gay-rights/.

- 2014c. “The World Congress of Families' Russian Network.” Mother Jones, February 21. https://www.motherjones.com/politics/2014/02/world-congress -families-us-evangelical-russia-family-tree/.

Luehrmann, Sonja. 2016. "Innocence and Demographic Crisis: Transposing Postabortion Syndrome into a Russian Orthodox Key." In A Fragmented Landscape: Abortion Governance and Protest Logics in Europe, edited by Silvia De Zordo, Joanna Mishtal, and Lorena Anton, 103-22. New York: Berghahn.

- 2017. “'God Values Intentions': Abortion, Expiation, and Moments of Sincerity in Russian Orthodox Pilgrimage." Hau: Journal of Ethnographic Theory 7(1):163-84.

Mac Donald, Sarah. 2017. "People Are Only Hearing Sterilised Version of Abortion, PLC Conference Hears." CatholicIreland.net, December 5. https://www .catholicireland.net/people-hearing-sterilised-version-abortion-plc-conference -hears/.

Marcotte, Amanda. 2010. "The Earth-Shaking Abortion That Never Happened." Slate, January 7. http://www.slate.com/blogs/xx_factor/2010/01/07/abby _johnsons_conversion_story_sounds_great_but_appears_to_be_false.html.

Marty, Robin. 2015. "Meet Joe Scheidler, Patriarch of the Anti-abortion Movement." Political Research Associates, January 23. https://www.politicalresearch.org /2015/01/23/meet-joe-scheidler-patriarch-of-the-anti-abortion-movement/.

- 2017. "Clinic Rescues Are Back—and They're Worse Than Ever." Dame, September 18. https://www.damemagazine.com/2017/09/18/clinic-rescues -are-back-and-theyre-worse-ever/.

Mason, Carol. 1999. “Minority Unborn.” In Fetal Subjects, Feminist Positions, edited by Lynn Marie Morgan and Meredith W. Michaels, 159-74. Philadelphia: University of Pennsylvania Press.

- 2002. Killing for Life: The Apocalyptic Narrative of Pro-life Politics. Ithaca, NY: Cornell University Press.

2018. "Right-Wing Literature in the United States since the 1960s." Oxford Research Encyclopedia of Literature. http://literature.oxfordre.com/view 
/10.1093/acrefore/9780190201098.001.0001/acrefore-9780190201098-e -34 .

McCorvey, Norma. 1997. Won by Love: Norma McCorvey, Jane Roe of Roe v. Wade, Speaks Out for the Unborn as She Shares Her New Conviction for Life. Nashville: Thomas Nelson.

MEMRI (Middle East Media Research Institute). 2017. "Russian Orthodox Prelate Predicts: Europe Will Turn Muslim in 30 Years, Russia in 50." Special dispatch, no. 6920, May 12. https://www.memri.org/reports/russian-orthodox-prelate -predicts-europe-will-turn-muslim-30-years-russia-50.

Mihailovic, Alexander. 2015. "Hijacking Authority: Academic Neo-Aryanism and Internet Expertise." In Digital Media Strategies of the Far-Right in Europe and the United States, edited by Patricia Anne Simpson and Helga Druxes, 83-102. Lanham, MD: Lexington.

Minnite, Lorraine C. 2012. "New Challenges in the Study of Right-Wing Propaganda: Priming the Populist Backlash to 'Hope and Change.' "New Political Science 34(4):506-26.

Mohanty, Ranjani Iyer. 2012. "Trash Bin Babies: India's Female Infanticide Crisis." Atlantic, May 25. https://www.theatlantic.com/international/archive/2012 /05/trash-bin-babies-indias-female-infanticide-crisis/257672/.

Morgan, Lynn M. 2017. "The Dublin Declaration on Maternal Health Care and Anti-abortion Activism: Examples from Latin America." Health and Human Rights Journal 19(1):41-53.

OllieGarkey. 2012. "Is an Anti-choice Group Using a Nazi Symbol?” Daily Kos, July 9. https://www.dailykos.com/stories/2012/7/9/1107487/-Is-an-Anti-Choice -group-using-a-Nazi-Symbol.

O'Loughlin, Ed. 2018. "As Irish Abortion Vote Nears, Fears of Foreign Influence Rise.” New York Times, March 26. https://www.nytimes.com/2018/03/26 /world/europe/ireland-us-abortion-referendum.html.

Paltrow, Lynn M., and Jeanne Flavin. 2013. "The Policy and Politics of Reproductive Health Arrests of and Forced Interventions on Pregnant Women in the United States, 1973-2005: Implications for Women's Legal Status and Public Health.” Iournal of Health Politics, Policv, and Law Advance Publication 38(2):299-343.

Parker, Christopher Sebastian, Sebastian Mayer, and Nicole Buckley. 2019. "Left, Right, but No In-Between: Explaining American Polarization and Post-factualism under President Trump." In Trumping the Mainstream: The Conquest of Democratic Politics by the Populist Radical Right, edited by Lise Esther Herman and James Muldoon, 112-29. New York: Routledge.

Parogni, Ilaria. 2016. "The Strategic Savvy of Russia's Growing Anti-abortion Movement." The Nation, August 30. https://www.thenation.com/article/the -strategic-savvy-of-russias-growing-anti-abortion-movement/.

Provost, Claire, and Lara Whyte. 2018. "Foreign and 'Alt-Right' Activists Target Irish Voters on Facebook ahead of Abortion Referendum." Open Democracy, April 25. https://www.opendemocracy.net/5050/claire-provost-lara-whyte /north-american-anti-abortion-facebook-ireland-referendum. 
Rivkin-Fish, Michele. 2003. "Anthropology, Demography, and the Search for a Critical Analysis of Fertility: Insights from Russia." American Anthropologist 105 (2):289-301.

- 2010. "Pronatalism, Gender Politics, and the Renewal of Family Support in Russia: Toward a Feminist Anthropology of 'Maternal Capital." Slavic Review 69(3):701-24.

- 2013. "Conceptualizing Feminist Strategies for Russian Reproductive Politics: Abortion, Surrogate Motherhood, and Family Support after Socialism." Signs 38(3):569-93.

Risen, James, and Judy L. Thomas. 1998. Wrath of Angels: The American Abortion War. New York: Basic.

Roberts, Dorothy. 1998. Killing the Black Body: Race, Reproduction, and the Meaning of Liberty. New York: Vintage.

Roof, Judith. 2015. "Out of the Bind: From Structure to System in Popular Narratives." In Warhol and Lanser 2015, 43-58.

Sanger, Carol. 2017. About Abortion: Terminatina Preanancv in Twentv-First Centurv America. Cambridge, MA: Belknap Press of Harvard University Press.

Saurette, Paul, and Kelly Gordon. 2016. The Changing Voice of the Anti-abortion Movement: The Rise of "Pro-Woman" Rhetoric in Canada and the United States. Toronto: University of Toronto Press.

Scheidler, Joseph M. 1985. Closed: 99 Ways to Stop Abortion. Toronto: Life Cycle Books.

Shanghai Daily. 2014. "China Handles 6,833 Cases of Illegal Gender Test, Abortion.” December 29. http://www.shanghaidaily.com/article/article_xinhua .aspx?id=261046.

Shekhovtsov, Anton. 2018. Russia and the Western Far Right: Tango Noir. London: Routledge.

Smith, James A., Sr. 2015. “'First-Ever' Evangelical Conference on Transgender Issues Set for Oct. 5 in Louisville.” Southern Baptist Theological Seminary, September 14. http://news.sbts.edu/2015/09/14/first-ever-evangelical-conference -on-transgender-issues-set-for-oct-5-in-louisville/.

Thomas, Rusty. 2016. "Open Letter to the Police in America." Operation Save America, July 19. http://www.operationsaveamerica.org/2016/07/19/press -release-open-letter-to-the-police-in-america/.

Trewhella, Matthew. 2013. The Doctrine of the Lesser Magistrates: A Proper Resistance to Tyranny and a Repudiation of Unlimited Obedience to Civil Government. North Charleston, SC: CreateSpace.

Tribe, Lawrence. 1992. Abortion: The Clash of Absolutes. New York: Norton.

Valerius, Karyn. 2013. "A Not-So-Silent Scream: Gothic and the US Abortion Debate." Frontiers 34(3):27-47.

Van Maren, Jonathon. 2014. "How Abolish Human Abortion Gets History Wrong." Canadian Centre for Bio-ethical Reform, January 15. https://www .endthekilling.ca/blog/2014/01/15/how-abolish-human-abortion-gets-history -wrong. 
Warhol, Robyn, and Susan S. Lanser, eds. 2015. Narrative Theory Unbound: Queer and Feminist Interventions. Columbus: Ohio State University Press.

Yeung, Miriam. 2015. "How Asian-American Women Became the Target of Antiabortion Activism." Washington Post, November 4. https://www.washingtonpost .com/posteverything/wp/2015/11/04/how-asian-american-women-became -the-target-of-anti-abortion-activism/?utm_term $=.03$ bef450e810.

Young, Maria. 2013. "Russia Gay Laws Cheered by US Conservatives." Sputnik News, March 8. https://sputniknews.com/analysis/20130803182557638-Russia -Gay-Homosexuality-Laws-Cheered-by-US-Conservatives/. 